\title{
Bioassay of Some Plant Oils against Termite, Odontotermes obesus (Isoptera: Termitidae)
}

\author{
Diksha Dutta $^{1}$, Inee Gogoi ${ }^{2}$ and Swapnalisha Mohapatra ${ }^{3 *}$ \\ Department of Entomology, College of Agriculture, Assam Agricultural University, \\ Jorhat- 785013, Assam, India \\ *Corresponding author
}

A B S T R A C T

Keywords

Odontotermes

obesus, LC50,

relative toxicity,

plant oils and

chlorpyriphos

Article Info

Accepted:

07 January 2019

Available Online:

10 February 2019
A laboratory bioassay was carried out to determine $\mathrm{LC}_{50}$ and relative toxicity of three plant oils along with check chlorpyriphos 20EC and control against termite, Odontotermes obesus. The data on mortality of Odontotermes obesus revealed that among the plant oils tested neem oil showed the lowest $\mathrm{LC}_{50}$ value (0.241) followed by karanj oil (0.636) and jatropha oil (2.130) after 72 hours exposure period. Considering the relative toxicity of chlorpyriphos as unit value the comparison of relative toxicity revealed that neem oil, karanj oil and jatropha oil were $0.066,0.025,0.008$ times less toxic than chlorpyriphos after 72 hours exposure period respectively. The order of relative toxicity was found in the following manner; neem oil >karanj oil >jatropha oil.

\section{Introduction}

With over 1 million different species in the world, insects have successfully colonized a great diversity of habitats. Particularly the soil is an ideal niche for insects providing protection from heat and cold, drying and heavy rains and natural enemies such as birds etc. Termite is one of the most important agricultural pest belong to the same habitat soil. A total of 2650 termite species found all over the world, in which 300 species have been recognized as pests (Kambhampati and Eggleton, 2000). They live in a nest or colony and each individual have different functional role according to the "caste system". They hold two positions from the economic point of view by damaging buildings, forestry, pastures and wide range of crops including cash crops also and at the same time beneficial in the conversion of dead trees and other plant products to substances that can be utilized by plants. Termites cause agricultural damage in several ways, firstly infest the crop itself and limit the yield (wheat, coconut, chili, mango, sorghum, sugarcane, cotton etc.). Secondly it can interfere with farming infrastructure such as by destroying poles that 
support fencing. Thirdly the termite can destroy containers used to ship agricultural products.

Control of termites has largely relied on broad spectrum and persistent organochlorine insecticides (Logan et al., 1990). Application of such synthetic insecticides in soil leads to an enormous side effects causing degradation of the soil health and thus affect the crop yield. In recent years, searching for environmentally safe methods to control insect pests have been carried out by using plant derivatives with significant insecticidal effects, which have been considered as new source of pesticides with negligible side effects on the environment (Balandrin et al., 1985).

Plant oils especially their important compounds offer promising alternatives for conventional insecticides and also act as excellent contact insecticides (Tapondjou et al., 2002), antifeedant or have repellent effects (Geer, 2005) and may also affect important biological parameters, such as growth rate, life span and reproduction (Rahmat et al., 2006). Keeping in view the above facts, the present investigation has been carried out with the following objective.

To determine $\mathrm{LC}_{50}$ and relative toxicity of some plant oils and chlorpyriphos against termite, Odontotermes obesus.

\section{Materials and Methods}

\section{Details of plant oils}

The laboratory experiment was conducted in 2015-16 with four treatments which included three plant oils and one standard check along with untreated control. Termites (Odontotermes obesus) were collected from farm nearby sugarcane field of Assam Agricultural University.
The details of the treatments are presented below:

$\mathrm{T}_{1}$. Neem oil (Azadirachta indica)

$\mathrm{T}_{2}$. Karanj oil (Pongamia pinnata)

$\mathrm{T}_{3}$. Jatropha oil (Jatropha curcas)

$\mathrm{T}_{4}$. Chlorpyriphos 20EC

$\mathrm{T}_{5}$. Untreated control

\section{Bioassay method}

For determination of $\mathrm{LC}_{50}$ values, the plant oils collected were considered as standard $(100 \%)$ and stock solution of known strength as well as the subsequent concentrations was prepared following flow chart. The bioassay was carried out using residual film method.

For this the different concentrations of each plant oils and chlorpyriphos 20EC was applied on the cellulose filter paper disc (size $4.5 \mathrm{~cm}$ dia) which was placed on the petriplate $(5 \mathrm{~cm}$ dia). Thin and uniform film of treatments was prepared by taking $1 \mathrm{ml}$ of plant oils and chlorpyriphos to the cellulose filter paper.

Ten (10) numbers of worker termite were released in to each petri plate, served as one replication. Three replications for each concentration of plant oils and chlorpyriphos was maintained. The solvent from the treated filter paper was air dried at room temperature. The filter paper treated with acetone only was used for control. The petri plates with covers then were placed into the incubator at $25 \pm 1^{\circ} \mathrm{C}$ and $80 \pm 5 \%$ RH and after 24, 48 and 72 hours, mortality counts were made.

The per cent mortality in each treatment was worked out and if there were mortality in the control, the observed mortality was corrected by using Abbott's formula (1925).

\section{Statistical analysis}

The experimental data were subjected to "Probit analysis" as described by Finney 
(1971). The median lethal concentration $\left(\mathrm{LC}_{50}\right)$ was obtained from the regression equation. The values of relative toxicity of neem oil, karanj oil, jatropha oil and chlorpyriphos were calculated as follows:

$$
\text { Relative toxicity }=\frac{\mathrm{LC}_{50} \text { value of chlorpyriphos }}{\mathrm{LC}_{50} \text { value of plant oils }}
$$

\section{Results and Discussion}

The data on mortality of $O$. obesus revealed that neem oil @ 2 per cent caused highest mortality of $61.02,72.55$ and 83.35 per cent after 24,48 and 72 hours whereas 2.50 per cent karanj oil caused mortality $(58.35 \%)$ at 24 hours as well as at 48 hours $(62.87 \%)$ and at 72 hours $(70.05 \%)$. For jatropha oil, mortality recorded was as 50.03, 67.66 and 71.92 per cent after 24,48 and 72 hours at 4.00 per cent, respectively. The data on mortality of worker termite was revealed that chlorpyriphos caused highest mortality in comparison to other treatments with 70.05 , 83.33 and 90.33 per cent after 24,48 and 72 hours, respectively at 0.04 per cent (Table 1 ).

The regression equation, $\mathrm{LC}_{50}$ values, relative toxicity, fiducial limit and the order of toxicity using plant oils and chlorpyriphos after 24,48 and 72 hours are calculated.

From the table it was found that neem oil and jatropha oil recorded lowest $(24 \mathrm{~h}=1.296$, $48 \mathrm{~h}=0.627$ and $72 \mathrm{~h}=0.241$ ) and highest $(24 \mathrm{~h}=4.054,48 \mathrm{~h}=2.986$ and $72 \mathrm{~h}=2.130) \mathrm{LC}_{50}$ whereas karanj oil reported 1.933,1.426 and 0.636 as $\mathrm{LC}_{50}$ value after 24,48 and 72 hours respectively (Table 2 and Fig. 1).

The comparison of relative toxicity revealed that neem oil was $0.023,0.032$ and 0.066 times less toxic than chlorpyriphos when exposed for a period of 24, 48 and 72 hours, respectively. Karanj oil was $0.016,0.014$ and
0.025 times less toxic than chlorpyriphos whereas jatropha oil was $0.007,0.006$ and 0.008 times less toxic than chlorpyriphos when exposed for a period of 24,48 and 72 hours, respectively.

The order of toxicity with respect to $\mathrm{LC}_{50}$ was chlorpyriphos>neem oil >karanj oil >jatropha oil for all the above mentioned exposure period. From the above Probit results, it was clear that all the tested plant oils were effective for controlling termite but neem oil was the most effective one.

The toxicity of neem, karanj and jatropha may be due to the presence of active chemical compound in these plants that shows toxicity against the insects.

The present works are in conformity with the work of Verma et al., (2011) who reported that the active ingredient karanjin of Pongamia pinnata and phorbol ester of Jatropha curcas at $0.5 \mathrm{gm} / \mathrm{ml}$ can cause 100 per cent mortality of termite after 6 hours and 12 hours, respectively. The $\mathrm{LC}_{50}$ levels of karanjin and phorbol esters fractions were 0.038 and $0.071 \mathrm{~g} / \mathrm{ml}$, respectively, after $24 \mathrm{~h}$ at a 95 per cent $(0.05)$ confidence limit.

Similarly works of Sharma et al., (2011) are in conformity to the present findings where he studied termicidal potential of non-edible oil seed cakes (jatropha, karanja, neem and mahua) and their crude active components (phorbol esters, karanjin, saponins and azadirachtin) in vitro and in vivo against termite, Odontotermes obesus at 1.25, 2.5 and 6.25 per cent concentration and reported that cold water extract of neem cake is better than hot water extract and cause 100 per cent mortality of termites at all concentration after 72 hour. Crude karanjin extract induced 83.3 per cent mortality after $2 \mathrm{~h}$ and 100 per cent after $4 \mathrm{~h}$. 
Int.J.Curr.Microbiol.App.Sci (2019) 8(2): 486-492

Table.1 Per cent mortality of Odontotermes obesus caused by several plant oils and Chlorpyriphos at different exposure period

\begin{tabular}{|c|c|c|c|c|}
\hline \multirow[t]{2}{*}{ Treatment } & \multirow{2}{*}{$\begin{array}{c}\text { Concentration } \\
(\%)\end{array}$} & \multicolumn{3}{|c|}{ Post-treatment mortality } \\
\hline & & $24 \mathrm{~h}$ & $48 h$ & $72 \mathrm{~h}$ \\
\hline Karanj oil & 2.50 & $58.35(49.46)$ & $62.87(52.18)$ & $70.05(56.72)$ \\
\hline do & 2.00 & $51.94(45.56)$ & $52.26(46.21)$ & $62.26(52.19)$ \\
\hline do & 1.50 & $42.33(40.54)$ & $48.11(43.63)$ & $59.46(50.35)$ \\
\hline do & 1.00 & $35.88(36.16)$ & $41.86(40.54)$ & $52.93(46.89)$ \\
\hline do & 0.50 & $28.47(32.01)$ & $36.22(36.87)$ & $48.33(43.63)$ \\
\hline do & 0.25 & $23.76(29.14)$ & $34.11(35.45)$ & $39.11(38.32)$ \\
\hline S.Ed( $( \pm)$ & & 6.24 & 3.01 & 3.74 \\
\hline $\mathrm{CD}(\mathrm{P}=0.05)$ & & 13.40 & 6.39 & 7.92 \\
\hline Neem oil & 2.00 & $61.02(51.26)$ & $72.55(58.32)$ & $83.35(65.92)$ \\
\hline do & 1.50 & $52.26(46.05)$ & $60.27(50.35)$ & $64.44(53.13)$ \\
\hline do & 1.00 & $41.99(40.32)$ & $52.92(46.74)$ & $62.26(52.19)$ \\
\hline do & 0.50 & $33.28(35.17)$ & $46.67(43.00)$ & $59.13(50.17)$ \\
\hline do & 0.20 & $23.76(29.08)$ & $36.06(36.87)$ & $48.59(44.11)$ \\
\hline do & 0.10 & $18.11(25.15)$ & $25.33(30.19)$ & $39.36(38.83)$ \\
\hline S.Ed $( \pm)$ & & 5.65 & 4.03 & 5.88 \\
\hline $\mathrm{CD}(\mathrm{P}=0.05)$ & & 11.99 & 8.54 & 12.46 \\
\hline Jatropha oil & 4.00 & $50.03(44.99)$ & $67.66(55.29)$ & $71.92(57.89)$ \\
\hline do & 3.50 & $46.02(42.69)$ & $55.52(48.07)$ & $62.26(51.99)$ \\
\hline do & 3.00 & $40.09(39.20)$ & $48.84(44.27)$ & $57.26(49.11)$ \\
\hline do & 2.50 & $31.51(34.12)$ & $38.56(38.31)$ & $50.48(45.15)$ \\
\hline do & 2.00 & $26.80(31.13)$ & $34.58(35.94)$ & $43.73(41.38)$ \\
\hline do & 1.50 & $21.16(27.32)$ & $27.24(31.40)$ & $36.93(37.37)$ \\
\hline S.Ed $( \pm)$ & & 5.00 & 4.70 & 4.09 \\
\hline $\mathrm{CD}(\mathrm{P}=0.05)$ & & 10.61 & 9.98 & 8.69 \\
\hline Chlorpyriphos & 0.040 & $70.05(56.72)$ & $83.33(65.78)$ & $90.33(71.81)$ \\
\hline do & 0.035 & $56.10(48.42)$ & $71.05(57.46)$ & $80.35(63.64)$ \\
\hline do & 0.030 & $44.10(41.61)$ & $62.66(52.28)$ & $73.90(59.20)$ \\
\hline do & 0.025 & $41.83(40.24)$ & $55.51(48.07)$ & $64.44(53.32)$ \\
\hline do & 0.020 & $37.99(38.02)$ & $48.85(44.27)$ & $59.45(50.35)$ \\
\hline do & 0.015 & $28.91(32.48)$ & 40.77 (39.57) & $50.18(44.99)$ \\
\hline do & Control & $3.33(9.79)$ & $6.66(14.83)$ & $10.00(18.42)$ \\
\hline S.Ed $( \pm)$ & & 4.69 & 5.83 & 6.18 \\
\hline $\mathrm{CD}(\mathrm{P}=0.05)$ & & 9.94 & 12.34 & 13.10 \\
\hline
\end{tabular}


Table.2 Estimated LC50 value, regression equation, heterogenety $(\chi 2)$, fiducial limit and order of relative toxicity for three plant oils and chlorpyriphosat 24,48 and 72 HAT

\begin{tabular}{|c|c|c|c|c|c|c|}
\hline Treatment & $\begin{array}{c}\text { Regression } \\
\text { Equation }\end{array}$ & $\begin{array}{l}\text { Heterogenety } \\
\chi^{2}\end{array}$ & $\begin{array}{c}\mathrm{LC}_{50} \\
(\%)\end{array}$ & $\begin{array}{c}\text { Fiducial } \\
\text { limit }\end{array}$ & $\begin{array}{l}\text { Relative } \\
\text { Toxicity }\end{array}$ & $\begin{array}{l}\text { Order of } \\
\text { Toxicity }\end{array}$ \\
\hline & & & 24 hour & & & \\
\hline Karanj & $\begin{array}{c}Y=0.261+ \\
0.910 X\end{array}$ & 43.159 & 1.933 & $\begin{array}{l}1.447 \\
3.042\end{array}$ & 0.016 & II \\
\hline Neem & $\begin{array}{c}Y=.099+ \\
.883 \mathrm{X}\end{array}$ & 34.874 & 1.296 & $\begin{array}{l}0.984 \\
1.871\end{array}$ & 0.023 & I \\
\hline Jatropha & $\begin{array}{c}Y=1.193+ \\
1.962 \mathrm{X}\end{array}$ & 21.997 & 4.054 & $\begin{array}{l}3.594 \\
4.897\end{array}$ & 0.007 & III \\
\hline \multirow[t]{2}{*}{ Chlorpyriphos } & $\begin{array}{c}Y=2.787+ \\
1.845 X\end{array}$ & 22.738 & 0.031 & $\begin{array}{l}0.028 \\
0.035\end{array}$ & 1.000 & - \\
\hline & & & 48 hour & & & \\
\hline Karanj & $\begin{array}{c}Y=0.103+ \\
0.670 \mathrm{X}\end{array}$ & 15.356 & 1.426 & $\begin{array}{l}1.162 \\
1.835\end{array}$ & 0.014 & II \\
\hline Neem & $\begin{array}{c}Y=0.166+ \\
0.818 X\end{array}$ & 15.771 & 0.627 & $\begin{array}{l}0.530 \\
0.746\end{array}$ & 0.032 & I \\
\hline Jatropha & $\begin{array}{c}Y=1.194+ \\
2.514 \mathrm{X}\end{array}$ & 31.891 & 2.986 & $\begin{array}{l}2.746 \\
3.301\end{array}$ & 0.006 & III \\
\hline Chlorpyriphos & $\begin{array}{c}\mathrm{Y}=3.600+ \\
2.129 \mathrm{X}\end{array}$ & 34.313 & 0.020 & $\begin{array}{l}0.017 \\
0.023\end{array}$ & 1.000 & - \\
\hline & & & 72 hour & & & \\
\hline Karanj & $\begin{array}{c}Y=0.141+ \\
0.718 X\end{array}$ & 15.564 & 0.636 & $\begin{array}{l}0.497 \\
0.774\end{array}$ & 0.025 & II \\
\hline Neem & $\begin{array}{c}Y=0.470+ \\
0.761 X\end{array}$ & 41.928 & 0.241 & $\begin{array}{l}0.147 \\
0.340\end{array}$ & 0.066 & I \\
\hline Jatropha & $\begin{array}{c}Y=.994+ \\
3.027 X\end{array}$ & 54.020 & 2.130 & $\begin{array}{l}1.880 \\
2.569\end{array}$ & 0.008 & III \\
\hline Chlorpyriphos & $\begin{array}{c}Y=4.961+ \\
2.772 X\end{array}$ & 58.856 & 0.016 & $\begin{array}{l}0.013 \\
0.019\end{array}$ & 1.000 & - \\
\hline
\end{tabular}


Fig.1 LC50 values and relative toxicity of three plant oils against termite, $O$. obesus at 24 hours (a), 48 hours (b) and 72 hours (c) exposure period

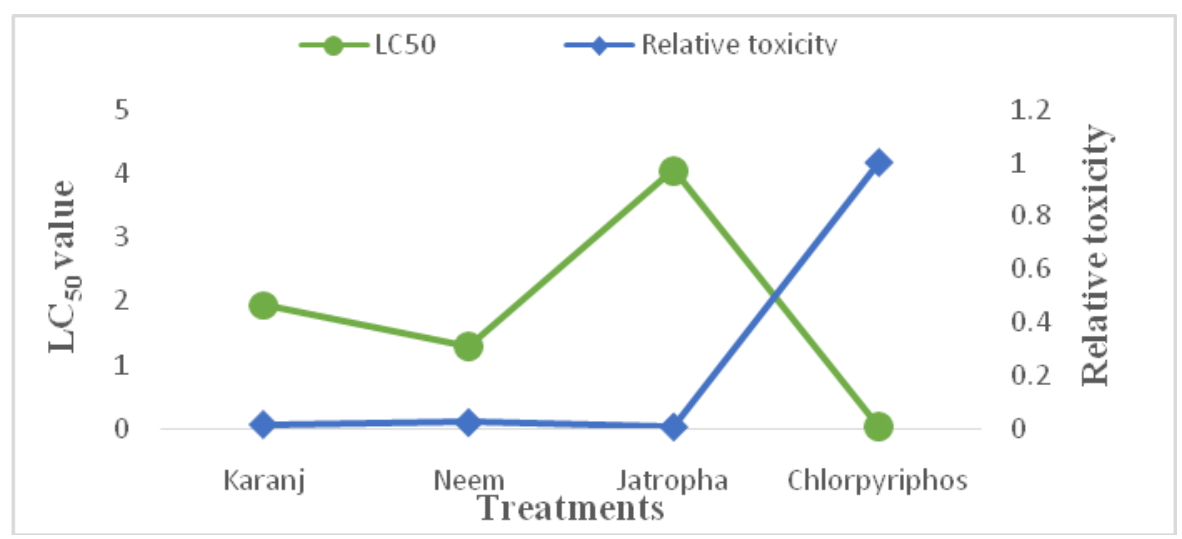

(a)

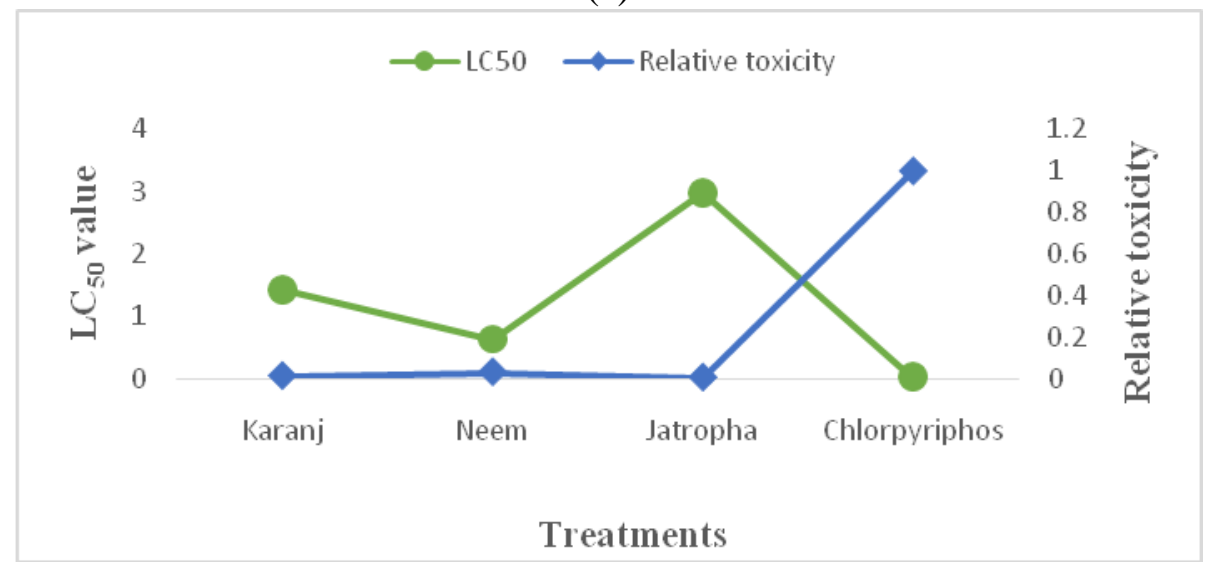

(b)

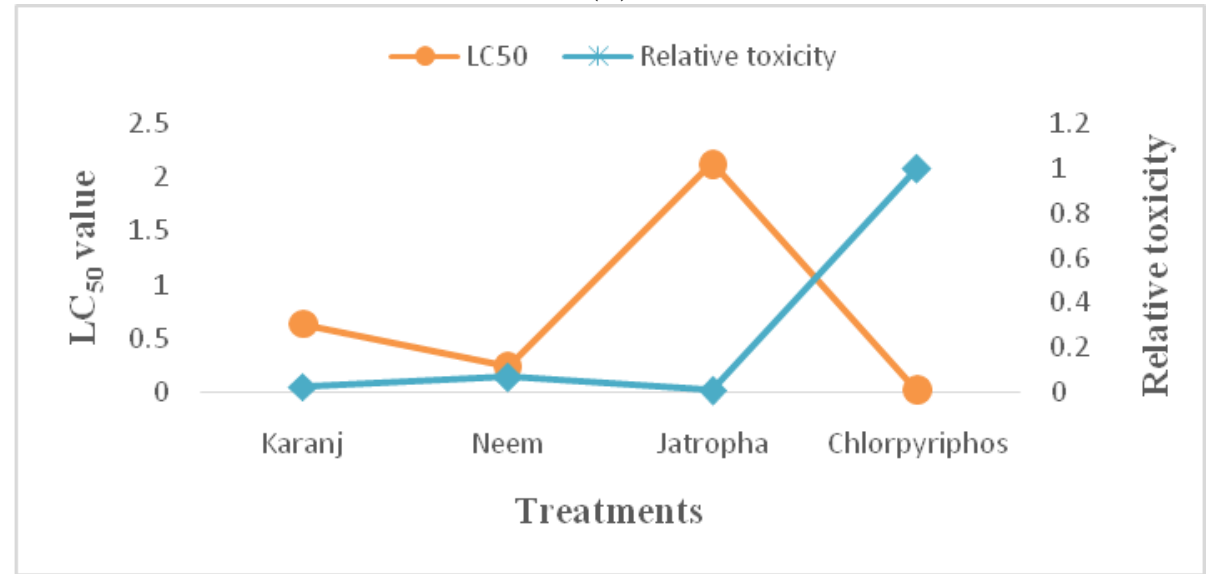

(c)

It may be concluded that the plant oils used had direct toxic effect. Among the tested oils neem oil showed the highest toxic effect which was followed by karanj oil and jatropha oil and most importantly these plants were available throughout India. So farmers can incorporate these oils for the management of termites in field condition. However, before 
releasing it as new technology further investigation is needed to confirm the result and more emphasis is to be given on studies associated with efficacy of plant and plant products against pests, their mode of action, identification of target sites and use of resistant strains.

\section{Acknowledgement}

The authors are thankful to Professor and Head, Department of Entomology, College of Agriculture, Jorhat and Director Post Graduate Studies, Assam Agricultural University, Jorhat, Assam for providing all the necessary facilities during the course of the study.

\section{References}

Abbot, W.S. 1925. A method of computing the effectiveness of an insecticide. Journal of Economic Entomology, 18: 265-267.

Balandrin, M.F., Klocke, J.A., Wurtele, E.S. and Bollinger, W.H. 1985. Natural plant chemicals: Sources of Industrial and Medicinal materials. Science, 228: 1154-1160.

Finney, D.J. 1971. Probit analysis, third ed. Cambridge University Press, Cambridge, United Kingdom.

Geer, S. 2005. Controlling termites without harmful chemicals. GEF, Washington DC, USA.

Kambhampati, S and Eggleton, P. 2000. Phylogenetics and taxonomy. In: Termites: Evolution, Sociality,
Symbioses, Ecology. Abe, T., D.E. Bignell, and M. Higashi, (eds.). Dordrecht: Kluwer Academic Publishing, Pp. 1-23.

Logan, J.W.M., Cowie, R.H. and Wood, T.G. 1990. Termites (Isoptera) control in agriculture and forestry by nonchemical methods. Bulletin of Entomological Research, 80:309-330.

Rahmat, A.S., Edrini-Ismail, P., Hin, T.Y.Y. and Bakar, M.F.A.B. 2006. Chemical constituents, antioxidant and cytotoxic effects of essential oil from Strobilanthes crispus and Lawsonia inermis. Journal of Biological Science, 6: 1005-1010.

Sharma, S., Verma, M., Prasad, R. and Yadav, D. 2011. Efficacy of nonedible oil seedcakes against termite Odontotermes obesus. Journal of Science and Industrial Research, 70: 1037-1041.

Tapondjou, L.A., Adler, C., Bouda, H. and Fontem, D.A. 2002. Efficacy of powder and essential oil from Chenopodium ambrosioides leaves as post-harvest grain protectants against six-stored product beetles. Journal of Stored Product Research, 38: 395402.

Verma, M., Pradhan, S., Sharma, S., Naik, S.N. and Prasad, R. 2011. Efficacy of karanjin and phorbol ester fraction against termites (Odontotermes obesus). International Biodeterioration and Biodegradation, 65: 877-882.

\section{How to cite this article:}

Diksha Dutta, Inee Gogoi and Swapnalisha Mohapatra. 2019. Bioassay of Some Plant Oils against Termite, Odontotermes obesus (Isoptera: Termitidae). Int.J.Curr.Microbiol.App.Sci. 8(02): 486-492. doi: https://doi.org/10.20546/ijcmas.2019.802.055 